удк 378:005.73

Роман Білик

Кам'янець-Подільський національний університет імені Івана Огієнка ORCID ID 0000-0003-3745-5810

DOI 10.24139/2312-5993/2020.09/110-120

\title{
РОЗРОБКА ТА ТЕОРЕТИЧНЕ ОБҐРУНТУВАННЯ СИСТЕМИ ПРОФЕСІЙНОЇ ПІДГОТОВКИ МАЙБУТНІХ ФАХІВЦІВ З ОХОРОНИ ПРАЦІ
}

у статті розглянуто систему професійної підготовки майбутніх фрахівців працеохоронної галузі в закладах профресійної освіти, під якою ми розуміємо відношення заданих прочесів, засобів і методів їх реалізації, що необхідні для забезпечення прогнозованого впливу на освітній процес підготовки майбутніх фахівців працеохоронної галузі з високим рівнем професійних та загальнолюдських якостей. Основними характеристиками цієї системи є: структурність, ієрархічність, цілісність, ідеологічна цілісність, взаємозв'язок з оточуючим середовищем, спроможність адаптуватися в умовах змінних зовнішніх факторів. Побудовано модель системи професійної підготовки майбутніх фрахівців з охорони праці в закладах профресійної освіти та обгрунтовано основні їі компоненти, зокрема: цільового, змістового, операчійного, процесуального, результативного блоків.

Ключові слова: охорона прачі, професійна освіта, система професійної підготовки, освітнє середовище, професійна компетентність.

Постановка проблеми. Проєвропейський напрям сучасної освіти, на який сьогодні орієнтується академічна спільнота України, рівень ї̈ доступності та якості обумовлюють постійне реформування освітньої галузі, складовою якої $\epsilon$ інженерно-педагогічна освіта, що реалізується закладами вищої освіти професійного та інженерно-педагогічного спрямування, факультетами інженерно-педагогічної підготовки й відповідними кафедрами інших закладів вищої освіти. Вона $є$ показником ефективності праці, рівня розвитку суспільно значущих та професійних якостей майбутніх фахівців професійної освіти робітників, бакалаврів та магістрів, підготовка яких реалізується у професійно-технічних закладах освіти, закладах вищої освіти III-IV рівнів акредитації.

Потреба в оновленні відчутна не лише в змісті і технологіях підготовки цих кадрів, а й у концепціях, підходах, програмах. Однак наукові розв'язки цих задач мають бути такими, які разом зі збереженням специфіки професійної освіти будуть забезпечувати закономірності її розвитку та прогресу.

Аналіз актуальних досліджень свідчить про те, що завдяки дослідженням змісту освіти сучасне суспільство накопичило багатий теоретичний та практичний досвід. Так, положенням теорії змісту освіти, його структури, видів і засобів засвоєння присвячені дослідження цілої низки 
науковців: В. Краєвського, В. Лєдньова, І. Лернера, М. Скаткіна, А. Хуторського. Зміст підготовки інженерів-педагогів розглядається у працях: С. Батишевої, В. Бажутіна, В. Безрукової, Е. Зеєра, а вітчизняні вчені Н. Брюханова, І. Васильєв, Т. Волкова, Р. Гуревич, О. Кириченко, О. Коваленко, Т. Яковенко продовжують дослідження в цьому аспекті. Разом із тим, в умовах інтеграції України до Європейського Союзу, підтримки положень Болонської декларації питання змісту освіти потребує глибокого вивчення, модернізації й удосконалення.

Метою статті $\epsilon$ теоретичне обґрунтування процедури формування системи професійної підготовки майбутніх фахівців з охорони праці.

Методи дослідження: для вирішення поставлених завдань на різних етапах дослідження нами використовувалися такі методи: теоретичні (аналіз і синтез філософських, психолого-педагогічних, техніко-технологічних понять; навчально-методичних видань; програм та нормативних актів 3 проблем професійної підготовки майбутніх фахівців охорони праці; узагальнення) - для розкриття змісту основних положень дослідження, виявлення в теорії та практиці сучасного стану професійної підготовки майбутніх фахівців з охорони праці; обґрунтування концепції і розробки моделі методичної системи формування фахових компетентностей фахівця працеохоронної галузі; визначення організаційних та педагогічних передумов; відбір змісту, форм, методів і засобів для ефективного формування професійного кредо майбутнього фахівця охорони праці; емпіричні (анкетування, тестування, контрольні роботи, педагогічне спостереження, педагогічний експеримент - з метою перевірки ефективності системи практичної підготовки майбутніх фахівців охорони праці; вивчення рівня сформованості найвищих рівнів професійних компетентностей (уміння, навички, переконання, готовність до вчинку, звичка, авторське педагогічне кредо) майбутнього фахівця працеохоронної галузі, у напрямі організації їх результативної діяльності впродовж активних педагогічних та виробничих практик, професійної діяльності в умовах реального виробничого середовища; математичної статистики (аналіз результатів наукових досліджень з використанням методів математичних статистики і визначення їх значущості) - для здійснення якісного й кількісного аналізу параметрів, які отримані в ході експериментальної роботи.

Виклад основного матеріалу. Відповідно до Болонської декларації, під якістю освіти розуміють систему компетентностей, які дають змогу встановлювати відповідну збалансованість між запитом суспільства в майбутніх фахівцях працеохоронної галузі і пропозицією кваліфікованих 
кадрів на ринку праці. Разом із тим, головним завданням, що постає перед професійною освітою на етапі інтенсивного розвитку сучасного суспільства, $\epsilon$ заміна викладацької парадигми (тобто передачі інформації) на парадигму навчання (формування компетентності) (Янчева, 2010, с. 3). Зважаючи на це, у системі сучасної освіти України відбувається поступова трансформація моделі підготовки фахівця (від кваліфікаційної до компетентнісної), яка надає більшу мобільність випускникам, оскільки не так жорстко прив'язана до конкретного об'єкта і предмета праці (Лук'янова, 2011, с. 18-20).

Професійна підготовка кваліфікованого фахівця з вищою освітою $€$ багатогранною системою, головним призначенням якої $\epsilon$ :

, генерування знань - проведення наукових досліджень та їх упровадження в практичну діяльність; розроблення нових освітніх програм, навчальних дисциплін та їх науково-методичний супровід;

, поширювання знань - підготовка та друк навчально-методичних посібників, монографій, наукових статей; участь у наукових конференціях, навчально-методичних семінарах та інших заходах 3 пропагування здорових та безпечних методів праці;

, освоєння знань - освітній процес із урахуванням рівня засвоєння знань залежно від методів, форм, засобів та освітніх технологій;

, формування в суб'єктів освітнього процесу вмінь, переконань та потреб до самовдосконалення й самонавчання протягом усього життя (Кузьмінський, 2005, с. 139).

Під терміном «система професійної підготовки» ми розуміємо відношення заданих процесів, засобів і методів їх реалізації, що необхідні для забезпечення прогнозованого впливу на освітній процес підготовки майбутніх фахівців працеохоронної галузі з високим рівнем професійних та загальнолюдських якостей. Система професійної підготовки - це кластер усіх факторів, що сприяє самовдосконаленню та реалізації поставлених цілей особистості.

Основними характеристиками системи є:

, структурність - існування взаємозв'язку та залежності між усіма компонентами системи (поєднання теоретичної підготовки фахівця з усіма видами практик);

, ієрархічність - усі компоненти підсистеми підпорядковуються системі загалом (розробка робочих навчальних програм відбувається відповідно до навчальних планів, які, у свою чергу, мають відповідати освітньо-професійним програмам); 
, цілісність - систему можна розглядати як інтегральний результат взаємодії всіх їі компонентів (гармонійне поєднання лекційних, практичних, лабораторних занять);

, ідеологічна цілісність - наявність провідної ідеї, що пронизує та об'єднує всі компоненти (кожна навчальна дисципліна має забезпечувати формування заданого прогнозованого результату навчання (компетентності));

взаємозв'язок з оточуючим середовищем - з системами вищого рівня (вимоги суспільства та науково-технічного прогресу до професійного рівня фахівця з охорони праці);

, спроможність адаптуватися в умовах змінних зовнішніх чинників (здатність адаптації майбутнього фахівця до специфіки виробничого середовища, тобто його здатність працювати в різних сферах народного господарства (Безрукова, 1999, с. 94-98).

На підставі теоретико-аналітичного аналізу та практичних результатів теми досліджень виявлено, що підготовка кваліфікованого фахівця працеохоронного напряму в умовах багаторівневої освіти $\epsilon$ ефективною, якщо в різнорівневих професійних закладах вищої освіти працеохоронного спрямування впроваджуватиметься система професійної підготовки, яка:

, ґрунтуватиметься на теоретичних принципах, що враховують як передовий вітчизняний педагогічний досвід професійної освіти, так і сучасні світові тенденції в освітньому просторі;

, має чітко визначену структуру, компоненти якої мають інтегровані зв'язки як по горизонталі через комплекс міждисциплінарних зв'язків, так і по вертикалі (коледж - заклад вищої професійної освіти);

, неперервна протягом усієї професійної діяльності та спрямована на збільшення кола професійних компетентностей, формування переконань та світогляду;

, застосовує передові педагогічні методи навчання, які здатні забезпечити мотивацію освітнього процесу, сформувати ключові, предметні та професійні компетентності.

Для відображення логіко-функціональної взаємодії багатопланових та численних факторів навчання ми побудували модель, яка відображає «процес навчання як систему, компоненти якої $€$ відображенням різних сторін (аспектів, характеристик) цілісного процесу навчання» (Підласий, 1996, с. 275): дидактична складова - об'єктивує процесуальні та змістовні компоненти освітнього процесу (зміст, форми, методи, засоби й цілі навчання тощо); гносеологічна складова - характеризує навчальний процес із позицій 
пізнання студентами власного «Я», об’єктивної реальності, явищ природи та закономірностей розвитку суспільства; психологічна складова - належить до внутрішньої пізнавальної (психічної) діяльності учасників освітнього процесу; кібернетичний компонент - $€$ відображенням усього різноманіття зв'язків навчального процесу, циркуляції потоків інформації й управління процесом ії засвоєння; соціологічна складова - $€$ відображенням відношень між усіма учасниками освітнього процесу, соціального значення процесу навчання; організаційний аспект - віддзеркалює освітній процес у плані інтелектуальної діяльності (організація процесу навчання та викладання, їх матеріальне забезпечення та стимулювання тощо).

У наших дослідженнях ми розглядаємо систему професійної підготовки майбутніх фахівців охорони праці як взаємообумовлену сукупність визначених компонентів (блоків), кожному з яких характерні інтегральні властивості та які формують між собою стійку єдність в організації педагогічного процесу формуванні професійних компетентностей майбутніх фахівців охорони праці в закладах професійної освіти (Гулай, 2013, с. 181190). У власному розумінні сучасну професійну підготовку майбутніх фахівців з охорони праці ми трактуємо як складну педагогічну систему, для якої характерні конкретний зміст, ієрархія структурних компонентів, форми взаємовідносин, які $\epsilon$ відображенням причинно-наслідкових зв'язків та об'єднують форми й методи організації освітнього процесу і способи розв'язку актуальних суперечностей, що постають під час професійної підготовки фахівця рівня вищої освіти «бакалавр» та «магістр».

Представлена нами система професійної підготовки майбутніх фахівців професійної освіти $€$ відображенням формальної складової процесу формування професійних компетентностей у закладах професійної освіти. Вона складається з наступних структурних блоків: цільового (освітня мета та завдання); змістового (професійний стандарт підготовки фахівця спеціальності 015 Професійна освіта (Охорона праці), Освітньо-професійна програма (ОПП), навчальний та робочі плани підготовки фахівця за даним напрямом, зміст дисциплін загальної та професійної підготовки, модульне об'єктно-орієнтоване динамічне навчальне середовище (MOODLE); фактори, що впливають на формування змісту підготовки - вимоги стейкхолдерів до кваліфікації фахівця й особисті інтереси та прагнення); операційного (практичні компоненти організації процесу фахової підготовки майбутніх фахівців з охорони праці, блоку педагогічних умов, які позначаються на формуванні професійних компетентностей майбутніх фахівців працеохоронної галузі); процесуального (концептуальні методологічні 
підходи, принципи та особливості організації освітнього процесу в ЗВО професійного спрямування); результативного (ґрунтується на визначенні рівня засвоєних знань шляхом проведення контролю показників результативності навчання, розробки еталонних критеріїв оцінювання). Модель системи професійної підготовки майбутніх фахівців з охорони праці в закладах професійної освіти (рис. 1) побудуємо за визначеною нами тріадою: вимоги ринку праці (вимоги стекйхолдерів) - фундаментальна підготовка професійна компетентність, здобуття яких відбувається максимальний педагогічний вплив, а майбутній фахівець має змогу реалізувати свої можливості, розвинути всі власні потенційні можливості та досягнути найвищого рівня професійної компетентності. Розглянемо основні компоненти моделі системи професійної підготовки майбутніх фахівців 3 охорони праці в закладах професійної освіти.

Цільовий блок визначає мету та цілі системи професійної підготовки майбутніх фахівців з охорони праці, що полягають у забезпеченні формування професійної компетентності майбутніх фахівців напряму підготовки «Охорона праці», що поєднує в собі глибокі фахові знання, уміння та навички, переконання, готовність до вчинку, звичка, авторське професійне кредо, об'єднані потребою в отриманні нових знань та використанні їх у професійній діяльності.

Змістовий блок визначає механізми та методи проєктування освітнього середовища підготовки фахівця спеціальності 015 Професійна освіта (за спеціалізаціями) першого (бакалаврського) та другого (магістерського) рівня вищої освіти. Разом із тим, зміст навчання визначається також вимогами стейкхолдерів і соціальним замовленням на підготовку високоосвіченого фахівця працеохоронної галузі.

Операційний блок визначає підходи, методи, форми організації та засоби організації освітнього процесу, які позитивно впливають на формування нестандартного, креативного мислення, виявлення власних потенційних можливостей та перспектив особистісного розвитку. Їх застосування дає змогу майбутньому фахівцю з охорони праці сформувати активну усвідомлену життєву позицію (переконання), обирати й досягати життєві і професійні цілі (готовність до вчинку), оцінювати власну діяльність і впливати на стратегію свого розвитку та самореалізації.

Важливе значення в інтерпретованій нами графічній моделі системи професійної підготовки майбутніх фахівців з охорони праці посідає підсистема педагогічних умов. До підсистеми педагогічних умов ми відносимо: 


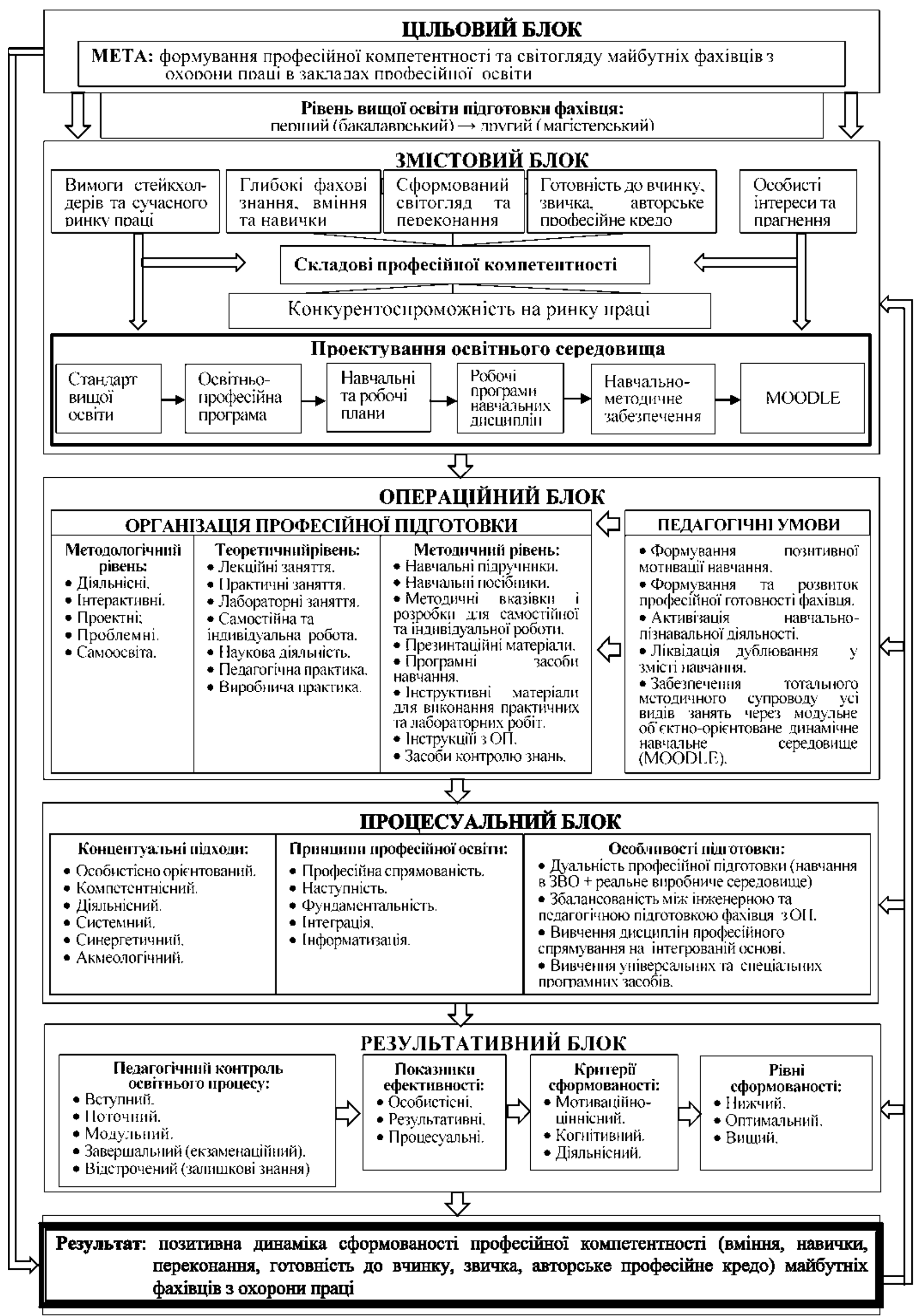

Рис. 1 Модель системи професійної підготовки майбутніх фахівців 3 охорони праці в закладах профеесійної освіти 
, формування позитивної мотивації в навчанні;

формування та розвиток професійної готовності фахівця;

, активізація навчально-пізнавальної діяльності відповідно до форми навчальної діяльності та індивідуальних особливостей студентів;

, ліквідація дублювання у змісті навчання;

, забезпечення тотального методичного супроводу всіх видів занять.

Процесуальний блок передбачає застосування концептуальних підходів (особистісно орієнтованого, компетентнісного, діяльнісного, системного, синергетичного, акмеологічного), принципів професійної освіти (професійна спрямованість, наступність, фундаментальність, інтеграція, інформатизація), що дає змогу організувати освітній процес як детерміновану діяльність майбутніх фахівців працеохоронної галузі 3 метою досягнення результату (формування професійних компетентностей) з урахуванням усіх особливостей їх фахової підготовки.

Результативний блок дає змогу ранжувати рівень освітніх досягнень студентів за кількістю отриманих балів за кожну навчальну тему чи змістовий модуль дисципліни, яка зумовлює необхідність в оцінюванні кожного виду діяльності студента. Цей блок включає педагогічний контроль: вступний, поточний, модульний, завершальний та відстрочений.

Одним із головних елементів результативного блоку $є$ показники ефективності діяльності майбутнього фахівця. Умовно ці показники поділяють на особистісні, результативні і процесуальні.

Переміщення між рівнями відбувається за такими векторами: у межах конкретних дисциплін; у межах певного рівня вищої освіти («бакалавр» чи «магістр»); у ході практичної професійної діяльності.

Результатом системи професійної підготовки майбутніх фахівців 3 охорони праці в закладах професійної освіти $\epsilon$ позитивна динаміка сформованості професійної компетентності (уміння, навички, переконання, готовність до вчинку, звичка, авторське професійне кредо) майбутніх фахівців з охорони праці, які мають схильність до саморозвитку та самоорганізації, творчого креативного мислення, проєктування ефективної високопродуктивної професійної діяльності.

Упровадження моделі системи професійної підготовки майбутніх фахівців з охорони праці сприяє поліпшенню ефективності їх підготовки на різних рівнях вищої освіти (на першому (бакалаврському) та другому (магістерському)) за рахунок розробки та впровадження узгоджених різнорівневих освітньо-професійних програм та навчальних планів, які враховують запити стейкхолдерів та студентів, а також вимоги сучасного 
виробництва до компетентності майбутнього фахівця. Упровадження в освітній процес сучасних інноваційних технологій навчання, поєднання теоретичної і практичної підготовки з реаліями та перспективами сучасного виробництва збільшує показник ефективності фундаментальної підготовки майбутніх фахівців працеохоронної галузі, задовольняє потребу студентів у повноцінній високоякісній підготовці під час навчання до майбутнього професійного становлення.

Упровадження зазначеної системи передбачає розробку комплекту методичного забезпечення, яке збільшить показник ефективності формування діяльнісних та когнітивних компонентів компетентності здобувачів за різними формами підготовки (стаціонарна, заочна, дистанційна).

Загалом, системи професійної підготовки майбутніх фахівців 3 охорони праці націлена на усунення протиріч, що й досі існують між теоретичними та практичними компонентами освітньої діяльності майбутніх фахівців працеохоронної галузі незалежно від рівня вищої освіти, який вони здобувають.

Висновки та перспективи подальших наукових розвідок. Удосконалення навчально-методичного забезпечення, методик навчання дисциплін професійного спрямування, оптимізація процесу проведення аудиторних занять, організація самостійної роботи студентів і педагогічний контроль підвищує показник рівня сформованості компетентності майбутнього фахівця. Застосування інновацій на всіх етапах освітнього процесу сприяють поліпшенню мотивації майбутніх фахівців, розвитку їх критичного мислення.

Аналізуючи категоріальні характеристики системи професійної підготовки майбутніх фахівців з охорони праці, доходимо до висновку відносно її властивостей - рефлективності, інтегрованості, технологічності:

, дослідження системи професійної підготовки майбутніх фахівців з охорони праці як багатоаспектного об'єкта варто здійснювати на основі оцінки функціональної повноти парадигм, зокрема знаннєвої, компетентністної, управлінської;

, наукові підходи до вивчення системи професійної підготовки майбутніх фахівців з охорони праці реалізовується шляхом аналізу статистичних даних і динаміки функціонування системи, процесів, що відбуваються в ній;

, системи професійної підготовки як науковий об'єкт забезпечує зв'язки педагогічної теорії та практики, визначає головні цінності для своїх основних компонентів (цілі, принципи, зміст, методи та форми діяльності) та технології процесу навчання, виховання, розвитку й адаптації людини в соціумі; 
, багаторівнева сутність системи професійної підготовки визначає інтеграцію рівнів ієрархії (індивідуальної системи, групи суб'єктів, колективу тощо), а також організацію, управління підсистем, спілкування між суб'єктами освітнього процесу

\section{ЛITEPATУРA}

Безрукова, В. С. (1999). Педагогика. Проективная педагогика. Екатеринбург (Bezrukova, V. S. (1999). Pedagogy. Project pedagogy. Yekaterinburg).

Гулай, О. І. (2013). Методичні основи фрормування фундаментальної складової професійної компетентності фахівців будівельного профілю. Луцьк (Hulai, O. I. (2013). Methodological basis for the formation of the fundamental component of the professional competence of construction professionals. Lutsk).

Кузьмінський, А. І. (2005). Педагогіка вищої школи. Київ (Kuzminskyi, А. І. (2005). Pedagogy of Higher Education. Kyiv).

Лук'янова, Л. (2011). Методологічні аспекти розроблення стандартів, заснованих на компетенціях. Профресійно-технічна освіma, 1, 18-20 (Lukianova, L. (2011). Methodological aspects of developing competency-based standards. Vocational education, 1, 18-20.

Пидласый, И. П. (1996). Педагогика. Москва: Просвещение, ВЛАДоС (Pidlasyi, І. Р. (1996). Pedagogy. M oscow: Prosveshchenye,VLADOS).

Янчева, Л. М., Кухарьонок, О. К., Левченко, А. В. (2010). Комунікативно-інтегрована система організації та управління навчальним процесом в умовах ступеневої освіти. Модернізація вищої освіти та проблеми управління якістю підготовки фрахівців. Теоретико-методологічні та практичні проблеми підготовки фрахівців за ступеневою системою освіти: матеріали VIII Всеукраїнської науково-методичної конференції, Україна, Харків: Харківський державний університет харчування та торгівлі (Yancheva, L. M., Kukharonok, O. K., Levchenko, A. V. (2010). M odernization of Higher Education and Problems of Quality Management in Specialist Training. Theoretical and methodological and practical problems of training specialists in the staggered system of education. Materials of the 8-rd All-Ukrainian Scientific and Methodological Conference, Ukraine. Kharkiv: Kharkov State University of Food and Trade).

\section{PEЗЮME}

Билык Роман. Разработка и теоретическое обоснование системы профессиональной подготовки будущих специалистов по охране труда.

В статье рассмотрена система профессиональной подготовки будущих специалистов трудоохранной области в учреждениях профессионального образования, под которой мы понимаем отношение заданных процессов, средств и методов их реализации, необходимых для обеспечения прогнозируемого воздействия на образовательный прочесс подготовки будущих специалистов трудоохранной отрасли с высоким уровнем профессиональных и общечеловеческих качеств. Основными характеристиками этой системы являются: структурность, иерархичность, челостность, способность адаптироваться в условиях изменяющихся внешних факторов. Нами построена модель системы профессиональной подготовки будущих специалистов с охраны труда в учреждениях высшего профессионального образования, обоснованы главные ее компоненты.

Ключевые слова: охрана труда, профрессиональное образование, система профессиональной подготовки, образовательная среда, профессиональная компетентность. 


\section{SUM MARY}

Bilyk Roman. Development and theoretical substantiation of the system of professional training of future specialists in labor protection.

In the article the system of professional training of future specialists of labour protection area in institutions of professional education is considered, under which we understand the relation of the given processes, means and methods of their realization, necessary for maintenance of predicted influence on educational process of training of future specialists of labour protection area with high level of professional and universal qualities. The main characteristics of this system are: structure, hierarchy, integrity, ideological integrity, relationship with the environment, ability to adapt to changing external factors. The model of the system of professional training of future specialists in labor protection in the institutions of professional education has been constructed and its main components have been substantiated, in particular: target content, operational, procedural, resultative blocks.

It is defined, that improvement of educational and methodological maintenance, methods of teaching disciplines of a professional direction, optimization of the process of conducting lessons, organization of independent work of students and the pedagogical control raises an indicator of the level of formation of competence of the future expert.

In our studies we consider the system of professional training of future occupational safety specialists as an interdependent totality of certain components (blocks), each of which is characterized by integral properties and forming a stable unity between themselves in the organization of pedagogical process of forming professional competences of future occupational safety specialists in vocational education institutions. In the proper sense, the modern professional training of future occupational safety specialists we interpret as a complex pedagogical system, which is characterized by a specific content, hierarchy of structural components, forms of relations, which are a reflection of cause-and-effect relations and unite forms and methods of educational process organization and ways to solve urgent contradictions arising during professional training of specialist of «Bachelor» and «M aster» levels of higher education.

Key words: labor protection, professional education, professional training system, educational environment, professional competence.

\section{Удк 378:504.06}

Світлана Бондарчук

Льотна академія Національного авіаційного університету

ORCID ID 0000-0001-5636-328X

DOI 10.24139/2312-5993/2020.09/120-130

\section{ДО ПИТАННЯ ПРО ФОРМУВАННЯ ДБАЙЛИВОГО СТАВЛЕННЯ ДО ДОВКІЛЛЯ МАЙБУТНІХ АВІАЦІЙНИХ ФАХІВЦІВ У ПРОЦЕСІ ПРОФЕСІЙНОЇ пІдготовки}

У статті розглянуто шляхи формування дбайливого ставлення до довкілля майбутніх авіаційних фахівців у процесі професійної підготовки. Розглянуто місце вищої школи в сталому розвитку. Проаналізовано роботи сучасних науковців, які займалися дослідженням зазначеної тематики. На прикладі Льотної академії Національного авіаційного університету запропоновано розглянути становлення дбайливого, небайдужого відношення до довкілля шляхом екологізації освіти та 